\title{
GENETIC EVALUATION OF SOME PRODUCTIVE LIFETIME TRAITS OF LOCALLY BORN FRIESIAN COWS IN EGYPT
}

\author{
M.M.I. Salem and M.H. Hammoud
}

Department of Animal and Fish Production, Faculty of Agriculture, University of Alexandria, Egypt

Received: 20/3/2019 Accepted: 12/5/2019

\section{SUMMARY}

Data on 2186 lactation records of 541 pure Friesian cows presenting 43 sires and 372 dams born at the Dairy Unit of Milk and Meat Project of the Faculty of Agriculture, Alexandria University, between 1983-2006 were utilized to evaluate lifetime milk yield (LMY), days in lactation ( $L D L)$, daily milk yield (LDMY) and number of lactations (NL) of Friesian cows. Also, the effects of season and year of calving andage at first calving on the previous traits were studied.

The least square means of LMY, LDL, LDMY and NLwere $18310 \mathrm{~kg}, 1318$ day, $13.6 \mathrm{~kg}$ and 4.04 lactations, respectively. Season of calving had no significant effect on all studied traits. Year of calving had significant effect $(P<0.01)$ on all studied traits. Age at first calving had significant effect $(P<0.05)$ on LDMY, but had no significant effect on $L M Y, L D L$ and $N L$.

The heritability estimates from univariate animal models were 0.272, 0.137, 0.117, and 0.116 for LMY, LDL, $L D M Y$ and $N L$, respectively. The moderate heritability for LMY emphasized the possibility of realizing a considerable rate of genetic improvement in this trait through selection programme. The genetic corrletions estimated from bivariate animal models were positive ranging from 0.264 to 0.993, except that between LMY and LDMYwas negative (-0.163). All correlations among all traits were significant $(P<0.01)$. The positive genetic correlations between $L M Y$ and each of $L D L$ and NL indicate that selection for any traits associated with genetic improvement in other traits. Phenotypic correlations among all traits were positive ranging from 0.099 to 0.966 and significant $(P<0.01$ or $P<0.05)$.

The breeding values for LMY, LDL, LDMY and NL of cows ranged between -759 and $1139 \mathrm{~kg},-101$ and 105 day, -1.77 and $1.82 \mathrm{~kg}$ and between -01.64 and 2.69 lactations, respectively, the corresponding values for dams were between -814 and $1107 \mathrm{~kg},-122$ and $100 \mathrm{day},-2.38$ and $1.53 \mathrm{~kg}$ and between -1.74 and 3.24 lactations, respectively. The breeding values for sires were between -560 and $748 \mathrm{~kg},-117$ and $83 \mathrm{day},-1.79$ and $1.26 \mathrm{~kg}$ and between -1.44 and 3.12 lactations for the respective traits. The genetic trends estimated by the regression of sires breeding values on time were positive and nonsignificant for $L M Y, L D L$ and NL and negative approached zero for LDMY. Generally, the results indicate that improvement of productive lifetime traits of Friesian cows could be obtained through both selection programme and improvement of management conditions.

Keywords: Heritability, genetic correlation, breeding values, genetic trend, productive lifetime traits, Friesian cows

\section{INTRODUCTION}

The ability of the cow to produce and reproduce for many years is a very important characteristic in dairy enterprises. Consequently, productive lifetime is generally considered as one of the most important economic traits in dairy cattle production (Tekerli and Kocak 2009, Singh et al. 2011, Jovanovac et al. 2013, Kefena et al. 2013, Martens and Bange 2013, Teke and Murat 2013, Novakovic et al. 2014, Jenko et al. 2015, Van Pelt et al. 2015, Horvath et al. 2017 and Mirhabibi et al. 2018). Increase productive lifetime affects profitability in a desired direction by reducing replacement costs and increasing the higher yielding cows in the herd (Brickell and Wathes 2011, Singh et al.2011, Jovanovac et al. 2013, Sasaki 2013, Van Pelt et al. 2015, Horvath et al. 2017 and Mirhabibi et al. 2018).

During the last three decades, milk yield per lactation has greatly increased, whereas fertility, health and productive life have decreased (Kanus 2009, Oltenacu and Broom 2010, Zink et al. 2012,
Pritchard et al. 2012, Martens and Bange 2013, Horvath et al. 2017 and Mirhabibi et al. 2018). Consequently, these traits have been considered in breeding programs in most countries all over the world (Oltenacu and Broom 2010, Zavadilová and Štípková 2012, Kargo et al. 2014, Olechnowicz et al. 2016, Mirhabibi et al. 2018 and Ward et al. 2018). Genetic improvement of lifetime productive traits by direct or indirect selection requires estimates of genetic parameters of these traits (Sadek et al.2009, Zavadilová and Štípková 2012, Zink et al. 2012, A1Samarai et al. 2013, Goshu et al. 2014, Stanojevic et al.2016 and Ward et al. 2018). Evaluation of the dairy cows' lifetime productive traits is important for developing breeding and management programs for genetic improvement; it helps in selection sires and dams with superior genetic merits (Jovanovac et al. 2013, Kern et al. 2014, Radwanet al. 2015, Kern et al. 2016, Abfalter et al. 2016, Olechnowicz et al. 2016 and Ward et al. 2018).

The objective of this investigation was to evaluate lifetime milk yield, days in lactation and daily milk 
yield and number of lactations of Friesian cows raised in a governmental dairy herd in Egypt. Also, the effects of season and year of calving and age at first calving on the considered traits were studied.

\section{MATERIALS AND METHODS}

\section{Source of data:}

Data used in this investigation were collected from 2186 lactation records relevant to 541 locally born pure Friesian cows which belong to the Dairy Unit of Milk and Meat Project of the Faculty of Agriculture, Alexandria University. This project has been established in 1982 and the records representing cows born during the period from 1983 to 2006. The traits under investigation were lifetime total milk yield in kilograms (LMY), days in lactation in days (LDL), daily milk yield in kilograms (LDMY) and number of lactations (NL).

\section{Herd management:}

Animals were housed free in shaded open yards, grouped according to their average daily milk yield, and fed ad libitum on berseem (Trifolium alexandrinum) from November till May and on Sorghum (Sorghum bicolor)along with berseem hay from June till October. They were also fed all year around on concentrate supplementary ration containing at least $14 \%$ crude protein and $65 \%$ total digestible nutrient. Feeding allowances were offered according to milk production and physiological status as recommended by NRC (1982 and 1989). Water was also available ad libitum. Heifers were artificially inseminated for the first time when reaching $350 \mathrm{kgs}$ of weight and pregnancy was detected by rectal palpation 60 days after service. The cows were machine milked twice a day at $06.00 \mathrm{~h}$ and $18.00 \mathrm{~h}$.

\section{Statistical analysis:}

Least squares of GLM procedure (SAS 2008) were utilized to test the significance of the fixed effects of season of calving (4 seasons), year of calving (8 periods) and age at first calving as a covariate. Month of first calving were classified by season into autumn's between September and November, winter's between December and February, spring's between March and May and summer's between June and August. Year of first calving was classified into six groups $(1=1985-1988,2=1989$ 1992, 3=1993 - 1996, 4= $1997-2000,5=2001-2004$ and $6=2005-2008)$. The statistical model fitted was:

$\mathbf{Y}_{\mathrm{ijkl}}=\boldsymbol{\mu}+\mathbf{S}_{\mathbf{i}}+\mathbf{T}_{\mathbf{j}}+\boldsymbol{\beta}\left(\mathrm{Age}_{\mathbf{i j k}}\right)+\mathbf{e}_{\mathbf{i j k l}}$ where, $\mathbf{Y}_{\mathbf{i j k l}}$ : either LMY, LDL, LDMY or NL; $\boldsymbol{\mu}$ : an underlying constant specific to each trait; $\mathbf{S}_{\mathbf{i}}$ : the fixed effect of $i^{\text {th }}$ season of calving ( $i=1,2,3$ and 4); $\mathbf{T}_{\mathbf{j}}$ : the fixed effect of $\mathrm{j}^{\text {th }}$ year of calving $(j=1,2,3 \ldots \ldots .11) ; \beta$ : the linear regression coefficient of each studied trait on age at first calving, as a covariable, Age $_{\mathrm{ijk}}$ : the deviation of age at first calving from its mean, as a co-variable, and $\mathbf{e}_{\mathbf{i j k}}$ : random residual assumed to be independent normally distributed with mean zero and variance $\sigma_{\mathrm{e}}^{2}$.
Variance and covariance components and genetic parameters were estimated using the Wombat programme (Meyer, 2006) fitting univariate and bivariate animal models. The assumed model was:

$\mathrm{y}=\mathrm{Xb}+\mathrm{Za}+\mathrm{e}$ where,

$y$ : a vector of observations, $b$ : a vector of fixed effects with an incidence matrix $X$, a: a vector of random animal effects with incidence matrix $Z$, and e: a vector of random residual effects with mean equals zero and variance $\sigma_{\mathrm{e}}^{2}$. The vector of additive (animal) effects (a) was assumed to be $\mathrm{N} \sim\left(0, A \sigma^{2}\right.$ ), where $\boldsymbol{A}$ is the numerator relationship matrix among animals in the pedigree file and $\sigma_{\mathrm{e}}^{2}$ is direct genetic variance. The vector of residual effects (e) was as sumed to be $\mathrm{N} \sim\left(0, \mathrm{I}^{2}{ }_{\mathrm{e}}\right)$, where $\mathbf{I}$ being the identity matrix, and $\sigma_{\mathrm{e}}^{2}$ is the residual variance $\operatorname{cov}(\mathrm{a}, \mathrm{e})=0$.

The genetic correlations between traits were estimated from bivariate animal model. The assumed model was:

$\left[\begin{array}{l}y_{1} \\ y_{2}\end{array}\right]=\left[\begin{array}{cc}x_{1} & 0 \\ 0 & x_{2}\end{array}\right]\left[\begin{array}{l}b_{1} \\ b_{2}\end{array}\right]+\left[\begin{array}{cc}z_{1} & 0 \\ 0 & z_{2}\end{array}\right]\left[\begin{array}{l}a_{1} \\ a_{2}\end{array}\right]+\left[\begin{array}{l}e_{1} \\ e_{2}\end{array}\right]$

Where $y_{i}=$ vector of observations, $b_{i}=$ vector of fixed effects, $a_{i}=$ vector of random animal effects for the $i^{\text {th }}$ trait, $e_{i}=$ vector of random residual effects for the $\mathrm{i}^{\text {th }}$ trait, and $\mathrm{X}_{\mathrm{i}}$ and $\mathrm{Z}_{\mathrm{i}}$ are incidence matrices relating records of the $i^{\text {th }}$ trait to the fixed and the random animal effects, respectively. It is assumed that:

$$
\operatorname{var}\left[\begin{array}{l}
a_{1} \\
a_{2} \\
e_{1} \\
e_{2}
\end{array}\right]=\left[\begin{array}{clrl}
g_{11} A & g_{12} A & 0 & 0 \\
g_{21} A & g_{22} A & 0 & 0 \\
0 & 0 & r_{11} & r_{12} \\
0 & 0 & r_{21} & r_{22}
\end{array}\right]
$$

Where $\mathrm{g}_{11}$ is the genetic variance for trait $1, \mathrm{~g}_{22}$ is the genetic variance for trait $2, g_{12}=g_{21}$ is the genetic covariance between both traits, $\mathrm{r}_{11}$ is the residual variance for trait $1, r_{22}$ is the residual variance for trait $2, r_{12}=r_{21}$ is the residual covariance between both traits

The genetic trends for the studied traits were computed as the regression coefficients of sires breeding values on their year of birth.

\section{RESULTS AND DISCUSSION}

The means, standard deviation (SD) and coefficient of variation ( $\mathrm{CV} \%$ ) of the studied traits are shown in Table (1). The means of LMY, LDL, LDMY and NL were $18309 \mathrm{~kg}, 1318$ day, $13.6 \mathrm{~kg}$ and 4.04 lactations, respectively. The means of LMY and NL were higher than those of being $9760 \mathrm{~kg}$ and 2.48 lactations, respectively documented by Khattab et al. (2009) on other herd of Friesian cows in Egypt. Moreover, the means of LMY, LDL and NL were higher than those being of $8831 \mathrm{~kg}, 35.8$ month and 3.34 lactations for LMY, LDL and NL, respectively depicted by Sadek et al. (2009) on Friesian cows in Egypt. On the other hand, the means of LMY and LDMY were lower than those of being 217796 and $18.63 \mathrm{~kg}$, respectively reported by Oudah et al. (2013) on a commercial herd of Friesian cows in 
Egypt. Whereas, the current means of LDL and NL

lactations obtained by Oudah et al. (2013).

were higher than those of 1230 day and 3.73

Table 1. Means, standard deviations (SD) and coefficient of variation (CV \%) of the studied traits

\begin{tabular}{lccc}
\hline Traits & Mean & SD & CV\% \\
\hline LMY (kg) & 18309.02 & 11356 & 52.84 \\
LDL (day) & 1317.91 & 738.09 & 48.26 \\
LDMY (kg) & 13.58 & 2.90 & 14.48 \\
NL (lactation) & 4.04 & 2.27 & 49.02 \\
No. of records & 2186 & & \\
\hline
\end{tabular}

LMY: lifetime milk y ield, LDL: lifetime days in lactation, LDMY: lifetime daily milk y ield and NL: number of lactations.

\section{Non-genetic effects:}

Season of calving had no significant effect on all studied traits, but year of calving had significant effect $(\mathrm{P}<0.01)$ on all traits (Table 2). Similar effects on LMY of Holstein cows in Egypt were documented by Abou-Bakr (2009). In India, Singh et al. (2011) depicted that season and year of birth had no significant effects on LMY and LDL of Sahiwal cattle. Age at first calving as a co-variable had significant effect $(\mathrm{P}<0.05)$ on LDMY, but had nonsignificant effect on LMY, LDL and NL (Table 2).
Contrary, Abou-Bakr (2009) reported that age at first calving had significant effect $(\mathrm{P}<0.01)$ on LMY. Moreover, Teke and Murat (2013) indicated that age at first calving had significant effects $(\mathrm{P}<0.05$ or $\mathrm{P}<0.001)$ on $\mathrm{LMY}$ and lifetime of Holstein cows in Turkey. In general, these effects could be attributed to the changes in climatic conditions and feeding regimes and managerial systems during different seasons and years.

Table 2. Effects of season and year of calving and age at first calving on the studied traits

\begin{tabular}{lccccc}
\hline \multirow{2}{*}{ Factors } & \multicolumn{7}{c}{ Traits } \\
\cline { 2 - 6 } & df & LMY & LDL & LDMY & NL \\
\hline Season of calving & 3 & NS & NS & NS & NS \\
Year of calving & $\mathbf{5}$ & $* *$ & $* *$ & $* *$ & NS \\
Age at first calving & 1 & NS & NS & $*$ & \\
Error & 531 & & & & \\
\hline
\end{tabular}

LMY: lifetime milk yield, LDL: lifetime days in lactation, LDMY: lifetime daily milk y ield and NL: number of lactations. NS: Not significant $(\mathrm{P}>0.05)$; *: Significant $(\mathrm{P}<0.05)$; **: Highly significant $(\mathrm{P}<0.01)$.

\section{Genetic and phenotypic parameters: Heritability $\left(h^{2}\right)$ :}

Estimates of variance components and heritability $\left(h^{2}\right)$ for all lifetime studied traits are presented in Table (3). Heritability estimates obtained in this study were $0.272,0.137,0.117$ and 0.116 for LMY, LDL, LDMY and NL. Moderate heritability estimates for LMY in this study indicate that improvement of this trait could be obtained through both selection program and improvement of management conditions. Whereas, low heritability estimates for LDL, LDMY and NL in this study indicated large environmental effects on these traits and reflected differences in their response to the existing environmental conditions. Similarly, moderate heritability estimate of 0.24 for LMY of Holstein cows was depicted by Abou-Bakr (2009). Khattab et al. (2009) reported moderate heritability estimate of 0.24 for LMY and low estimate of 0.12 for NL of Friesian cows. In Iraq, Sadek et al. (2009) depicted moderate heritability estimates of $0.29,0.29$ and 0.25 for LMY, LDL and
NL, respectively. Al-Samari et al. (2013) reported low heritability estimates of 0.10 and 0.02 for LMY and NL of Holstein cows. Oudah et al. (2013) documented heritability estimates of $0.268,0.365$, 0.024 and 0.401 for LMY, LDL, LDMY and NL of Friesian cows. In Serbia, Stanojevic et al. (2016) indicated low heritability estimates of 0.067 and 0.0747 for LMY and NL of Holstein cows, respectively. In India, Vintohraj et al. (2016) indicated heritability estimates of $0.095,0.044$ and 0.073 for LMY, LDL and LDMY, respectively of Jersey x Red Sindhi crossbred cows. In Libya, Ward et al. (2018) reported heritability estimates of 0.18 , 0.19 and 0.30 for LMY, LDL and LDMY, respectively. In view of the wide range of heritability estimates with other studies, there is good evidence that genetics plays a moderately large part, in determining variations in LMY and certain associated characters.

Table 3. Additive genetic $\left(\sigma_{\mathrm{a}}^{2}\right)$, environmental $\left(\sigma_{\mathrm{e}}^{2}\right)$ and phenotypic variances $\left(\sigma_{\mathrm{p}}^{2}\right)$, and heritability $\left(\mathrm{h}^{2}\right)$ for the studied traits.

\begin{tabular}{lcccc}
\multicolumn{1}{c}{ Traits } & $\boldsymbol{\sigma}_{\mathbf{a}}^{\mathbf{2}}$ & $\boldsymbol{\sigma}_{\mathbf{e}}^{\mathbf{2}}$ & $\boldsymbol{\sigma}_{\mathbf{P}}$ & $\mathbf{h}^{\mathbf{2}}(\mathbf{S E})$ \\
\hline LMY & 0.243 & 0.650 & 0.893 & $0.272(0.018)$ \\
LDL & 6750.3 & 42476 & 49226. & $0.137(0.091)$ \\
LDMY & 2.505 & 18.830 & 21.335 & $0.117(0.097)$ \\
NL & 3.457 & 26.373 & 29.830 & $0.116(0.090)$ \\
\hline
\end{tabular}

LMY: lifetime milk yield, LDL: lifetime days in lactation,

LADM: lifetime daily milk yield and NL: number of lactations. 


\section{Genetic correlations:}

Table (4) shows that genetic correlations among the studied traits were positive ranging from 0.264 to 0.993, except thatbetween LMY and LDMY was negative (-0.163). All correlations among all traits were significant $(\mathrm{P}<0.01)$. The positive genetic correlations among LMY, LDL and NL would result in a correlated response when selecting for LMY and consequently could produce genetic improvement in these correlated traits. However, the low negative genetic correlation between LMY and LDMY could result in negligible deleterious in the former when selection is applied on the latter. Therefore, high milk producers may not be the first choice for total merit amelioration. Khattab et al. (2009) obtained genetic correlations of 0.50 between LMY and NL of Friesian cows. Sadek et al. (2009) documented extremely high positive genetic correlations of $0.99,0.96$ and 0.98 between LMY and LDL, LMY and NL and between LDL and NL of Friesian cows, respectively. Oudah et al. (2013) depicted significant $(\mathrm{P}<0.01)$ positive genetic correlations ranged from 0.261 to 0.998 among LMY, LDL, LDMY and NL of Friesian cows. The genetic correlation between two traits is mainly due to genes that have effects on both traits. Genetic correlations have always been important part of carefully constructed breeding programs.

Table 4. Genetic (below diagonal) and phenotypic correlations (above diagonal) and standard errors (SE) among the studied traits

\begin{tabular}{lcccc}
\hline \multicolumn{1}{c}{ Traits } & LMY & LDL & LDMY & NL \\
\hline LMY & & $0.966^{* *}(0.002)$ & $0.247^{* *}(0.049)$ & $0.597^{* *}(0.028)$ \\
LDL & $0.993^{*}(0.008)$ & & $0.198^{* *}(0.051)$ & $0.625^{*}(0.026)$ \\
LDMY & $-0.163^{* *}(0.404)$ & $0.928^{* *}(0.588)$ & & $0.099^{*}(0.580)$ \\
NL & $0.264^{*}(0.901)$ & $0.561^{* *}(0.679)$ & $0.615^{* *}(0.679)$ & \\
\hline
\end{tabular}

LMY: lifetime milk yield, LDL: lifetime days in lactation, LDMY: lifetime daily milk yield and NL: number of lactations.

* Significant $(\mathrm{P}<0.05) * *$ : Highly significant $(\mathrm{P}<0.01)$.

\section{Phenotypic correlations:}

Phenotypic correlations among the studied traits were significant $(\mathrm{P}<0.05$ or $\mathrm{P}<0.01)$ positive ranging from 0.099 to 0.966 (Table 4). Oudah et al. (2013) documented positive phenotypic correlations ranged from 0.050 to 0.900 among LMY, LDL, LDMY and NL of Friesian cattle. Khattab et al. (2009) reported positive phenotypic correlations of 0.30 between LMY and NL of Friesian cows. Sadek et al. (2009) reported extremely high positive phenotypic correlations of 0.97, 0.91 and 0.95 between LMY and LDL, LMY and NL and between LDL and NL of Friesian cows, respectively. Oudah et al. (2013) indicated significant $(\mathrm{P}<0.01)$ positive phenotypic correlations ranged from 0.519 to 0.900 among LMY, LDL, LDMY and NL of Friesian cows except that between LDLand LDMY was being of 0.050. Also, Ward et al. (2018) depicted high positive phenotypic correlation of 0.78 between LMY and LDMY. The phenotypic correlation is due to genetic effects that are in common for the two traits, as well as environmental effects that affect both traits.

\section{Breeding values:}

Estimates of breeding values (BV) for cow, dams and sires for all studied traits are presented in Table (5). Breeding value defined as the total genetic ability of an animal for a given trait. Therefore, breeding value refers to the value of an animal in a breeding program for a particular trait. In practice, breeders want to know the level of performance that can be expected from progeny of certain individuals. The present breeding values for cows ranged between -759 and $1139 \mathrm{~kg},-101$ and 105 day, -1.77 and $1.82 \mathrm{~kg}$ and between -1.64 and 2.69 lactations for LMY, LDL, LDMY and NL, respectively, the corresponding values for dams were between -814 and $1107 \mathrm{~kg},-123$ and 100 day, -2.38 and $1.53 \mathrm{~kg}$ and between -1.74 and 3.24 lactations, respectively. The breeding values for sires were between -560 and $748 \mathrm{~kg},-117$ and 83 day, -1.79 and $1.26 \mathrm{~kg}$ and between -1.44 and 3.12 lactations for the respective traits. Khattab et al. (2009) documented breeding values for Friesian cows, dams and sires varied between -2141and 4379, -12721 and 2241and between -2525 and $4021 \mathrm{~kg}$ and between -0.7and 1.3, 0.5 and 0.4 and between -0.7 and 0.5 lactation for LMY and NL, respectively. Oudah et al. (2013) reported breeding values for Friesian sires ranged between -931 and $3692 \mathrm{~kg},-224$ and 164 day, between -0.128 and $0.144 \mathrm{~kg}$ and between -0.718 and 0.607 lactation for LMY, LDL, LDMY and NL, respectively. In general, estimation of the breeding values is necessary for the application of an optimal breeding strategy seeking the genetic improvement of the dairy cows' performance traits.

Table 5. Breeding values of cows, dams and sires for the studied traits

\begin{tabular}{lccccccccc}
\hline \multirow{2}{*}{ Trait } & \multicolumn{3}{c}{ Cow breeding } & values & \multicolumn{3}{c}{ Dam breeding values } & \multicolumn{2}{c}{ Sire breeding values } \\
\cline { 2 - 9 } & Min. & Max. & Range & Min. & Max. & Range & Min. & Max. & Range \\
\hline LMY (kg) & -759 & 1139 & 1898 & -814 & 1107 & 1921 & -560 & 748 & 1300 \\
LDL (day) & -101 & 105 & 206 & -122 & 100 & 222 & -117 & 83 & 200 \\
LDMY (kg) & -1.77 & 1.82 & 3.59 & -2.38 & 1.53 & 3.91 & -1.79 & 1.26 & 3.05 \\
NL (lactation) & -1.64 & 2.69 & 4.33 & -1.74 & 3.24 & 4.90 & -1.44 & 3.12 & 4.52 \\
\hline
\end{tabular}

LMY: lifetime milk yield, LDL: lifetime days in lactation, LDMY: lifetime daily milk yield and NL: number of lactations. 


\section{Genetic trends:}

The genetic trends estimated as the regression coefficients of estimated breeding values of sires on time were positive and non-significant for LMY, LDL and NL, but negative and non-significant for LDMY (Table 6). This might be attributed to the use semen of sires usually with variable genetic background from different sources. No apparent specific genetic trend which reflected the lack genetic progress achieved overtime, indicated the need for designing an effective long-term breeding program to improve productive lifetime traits of Friesian cows in this herd through selection and planned mating with semen of sires which possess high ETA for milk production and fertility obtained from trustable genetic source.

Table 6. Regression coefficients $(b \pm S E)$ of estimated breeding values of sires on their birth year for the studied traits

\begin{tabular}{lc}
\hline & Sire breeding values \\
\cline { 2 - 2 } Traits & $\mathbf{b} \pm \mathbf{S E}$ \\
\hline LMY (kg) & $2.738^{\mathrm{NS}} \pm 6.303$ \\
LDL (day & $0 . .154^{\mathrm{NS}} \pm 0.823$ \\
LDMY (kg) & $-0.004^{\mathrm{NS}} \pm 0.014$ \\
NL (lactation) & $0.003^{\mathrm{NS}} \pm 0.018$ \\
\hline
\end{tabular}

LMY: lifetime milk yield, LDL: lifetime days in lactation, LDMY: lifetime daily milk yield and NL: number of lactations. NS: Not significant $(\mathrm{P}>0.05)$.

\section{CONCLUSIONS}

The moderate heritability for LMY emphasized the possibility of realizing a considerable rate of genetic improvement in this trait through selection program. Selection with high emphasis on LMY will likely affect LDL and NL since its genetic correlations with these traits were highly and mildly positive. Low heritability estimates for LDL, LDMY and NL indicated that the differences in these traits of Friesian cows in this herd were mainly due to different nutritional, climatic conditions and management practices prevalent over different times. The low genetic trends of sires for all studied traits reflected the lack genetic progress achieved overtime. In general, the results indicate that improvement of productive lifetime traits of Friesian cows could be obtained through both selection program and improvement of management conditions.

\section{ACKNOWLEDGMENT}

The authors are grateful to Prof. Dr. Mamdouh A. Samak, and Prof. Dr. Ali M. Allam, the previous director managers of the Project, to the late Dr. Ahmed A. Radwan, the previous manager of the Project and to the late Mr. Khaled Abdel-Aziz Amin, the previous dairy specialist of the Project for their kind help and cooperation in data collection.

\section{REFERENCES}

Abfalter, K., W. Brade and O. Distl, 2016. Comparison of breeding values among cows with exceptional longevity and their contemporary herdmates in German Holsteins. Arch. Anim. Breed., 59: 71-77.

Abou-Bakr, S., 2009. Genetic and phenotypic parameters of some lifetime and longevity traits in Holstein cows of commercial farm in Egypt. Egyptian J. Anim. Prod., 46: 11-18.
Al-Samarai, F. R., S. S. Khalaf and F.H. Al-Zaydi, 2013. Estimation of correlated response in some lifetime traits according to other traits in Holstein cows. Int. J. Adv. Biol. Res. (IJABR), 3: 227-230.

Brickell, J.S. and D.C. Wathes, 2011. A descriptive study of the survival of Holstein-Friesian heifers through in third calving on English dairy farms. J. Dairy Sci., 94: 1831-1838.

Goshu, G., H. Singh, K. Petersson and N. Lundeheim, 2014. Heritability and correlation among first lactation traits in Holstein cows at Holeta Bull Dam Station, Ethiopia. Int. J. Livest. Prod., 5: 47-53.

Horvath, J., Z. Toth and E. Miko, 2017. The analysis of production and culling rate with regard to the profitability in dairy herd. Adv. Res. Life Sic. (ARLS), 1: 48-52.

Jenko, J., T. Perpar, and M. Kovač, 2015. Genetic relationship between the lifetime milk production, longevity and first lactation milk yield in Slovenian Brown cattle breed. Mljekarstvo, 65:111-120.

Jovanovac, S., N. Raguž, J. Sölkner and G. Mészáros, 2013. Genetic evaluation for longevity of Croatian Simmental bulls using a piecewise Weibull model. Arch. Tierz., 56: 89 - 101.

Kanus, W., 2009. Dairy cows trapped between performance demand and adaptability. J. Sci. Food Agrc., 89: 1107-1114.

Kargo, M., L. Hjorto, M. Toivonen, J.A. Eriksson, G.P. Aamand and J. Pedersen, 2014. Economic basis for the Nordic Total Merit Index. J. Dairy Sci., 97: 7879-7888.

Kefena, E., H. Diriba, S. Molla and S.H. Roman, 2013. Analysis of longevity traits and lifetime productivity of crossbred dairy cows in the Tropical Highlands of Ethiopia. J. Cell Anim. Biol., 7: 138-143.

Kern, E.L., J.A. Cobuci, C.N. Costa, J.B. Neto, G.S. Campos and C.M. McManus, 2014. Genetic parameters for longevity measures in Brazilian 
Holstein cattle using linear and threshold models. Arch. Tierz., 57: 1-12.

Kern, E.L., J.A. Cobuci, C.N. Costa, and V. Ducrocq, 2016. Survival analysis of productive life in Brazilian Holstein using a piecewise Weibull proportional hazard model. Livest. Sci., 185: 8996.

Khattab, A.S., H. Grosu, and A.M. Hussein, 2009. Estimation of genetic parameters and breeding values for lifetime production traits for Friesian cattle in Egypt. Archiva Zootechnica, 12: 82-86.

Martens, H and Chr. Bange, 2013. Longevity of high producing cows: a case study. Lohmann Information, 48: 153-157.

Meyer, K., 2006. WOMBAT-Digging deep for quantitative genetic analyses by restricted maximum likelihood. Proc. $8^{\text {th }}$ World Congress of Genetics Applied for Livestock. Production, Communication No. 27-14.

Mirhabibi, S., N. Kashan, S. Gharahveysi, 2018. Genetic Evaluation of Survival Traits in the Holstein Dairy Cows of Iran. Egypt. J. Vet. Sci., 49: 71-74.

Novakovic, Z., D. Ostojic-Andric, V. Pantelic, R. Beskorovajni, N. Popovic, M. Lazarevic and D. Niksic, 2014. Lifetime production of highyielding dairy cows. Biotechnol. Anim. Husb., 30: 399-406.

NRC, 1982. Nutrient requirements of dairy cattle. National Academy of Science, National Research Council. Washington, D.C. USA.

NRC, 1989. Nutrient requirements of dairy cattle. $6^{\text {th }}$ edition. National Academy of Science, National Research Council. Washington, D.C. USA.

Olechnowicz, J., P. Kneblewski, J.M. Jaśkowski and J. Włodarek, 2016. Effect of selected factors on longevity in cattle: A review. The J. Anim. Plant Sci., 26: 1533-1541.

Oltenacu, P. A. and D. M. Broom, 2010. The impact of genetic selection for increased milk production on the welfare of dairy cows. Anim. welfare, 19: 39-49.

Oudah, E.Z.M. , N.A. Shalaby, A.S.A. El Barbary and M. Helmy, 2013. Estimation of genetic parameters and breeding values for longevity traits for Friesian Cattle in Egypt. The $4^{\text {th }}$ International Conference on Sustainable Animal Agriculture for developing countries (SAADC=2013), 27-31 July 2013 Lanzhou Universities, Lanzhou, China.

Pritchard, T., M. Coffey, R. Mrode and E. Wall, 2012. Genetic parameters for production, health, fertility and longevity traits in dairy cows. Animal., 7: 34-46.

Radwan, H.A.A., E.A. Abo Elfadl and A.M. Fardos, 2015. Estimates of population parameters for some economic traits in Holstein Friesian cows by using statistical program. Global Veterinaria, 14: $129-135$.

Sadek, M.H., A.A. Halawa, A.A. Ashmawy and M. F. Abdel Glil, 2009. Phenotypic and genetic parameters estimation of first lactation, life-time yield and longevity traits in Holstein cattle. Egypt. J. Genet. Cytol., 38: 127-136.

SAS, 2008. Statistics Analysis System user's Guide, (Release 9.2). SAS Institute Inc., Cary, North Carolina, USA.

Sasaki, O., 2013. Estimation of genetic parameters for longevity traits in dairy cattle: A review with focus on the characteristics of analytical models. Anim. Sci. J., 84: 449-460.

Singh, U., A. Kumar, S. Kumar and B. K. Beniwal, 2011. Evaluation of Sahiwal cattle for lifetime traits on organized herd. Indian J. Anim. Sci., 81: 708-710.

Stanojevic, D., R. Dedovic, V. Bogdanovic, N. Raguz, M. Popovac, D. Jankovic and L. Strbac, 2016. Evaluation of the heritability coefficients of longevity in the population of Black and White cows in Serbia. Mljekarstvo, 66: 322-329.

Tekerli, M. and S. Kocak, 2009. Relationships between production and fertility traits in first lactation and lifetime performances of Holstein cows under subtropical conditions. Arch. Tierz., 52: $364-370$

Teke, B. and H. Murat, 2013. Effect of age at first calving on first lactation milk yield, lifetime milk yield and lifetime in Turkish Holsteins of the Mediterranean Region in Turkey. Bulgarian J. of Agric. Sci., 19: 1126-1129.

Van Pelt, M.L., T.H.E. Meuwissen, G. de Jong and R.F. Veerkamp, 2015. Genetic analysis of longevity in Dutch dairy cattle using random regression. J. Dairy Sci., 98: 4117-4130.

Vinothraj, S., A. Subramanian, R. Venkataramanan, Cecilia Joseph and S.N. Sivaselvam, 2016. Lifetime production performance of Jersey $\mathrm{x}$ Red Sindhi crossbred cows. Livest. Res. Int., 4: 59-62.

Ward A.M., O.M. Abuargob, A.A. Aswehli, R.A. Al Zlitne, S.Y. Ruban, T.M. Elgusbi, I.M. Hdud, 2018. Selection of healthy and highly productive dairy cattle. Int. J. Progr. Sci. Technol. (IJPSAT), 8: 164-170.

Zavadilová, L. and M. Štípková, 2012. Genetic correlations between longevity and conformation traits in the Czech Holstein population. Czech J. Anim. Sci., 57: 125-136.

Zink, V., J. Lassen and M. Stipkova, 2012. Genetic parameters for female fertility and milk production traits in first-parity Czech Holstein cows. Czech J. Anim. Sci., 57: 108-114. 


\title{
التقييم الور اثي لبعض صفات طول الحياة الإنتاجية لأبقار الفريزيان المولوده محلياً في مصر
}

\section{محمد محمود سالم ، محمد حسن حمود}

\author{
قسم الإنتاج الحيواني والسمكي-كلية الزراعةـ جامعة الإسكندرية
}

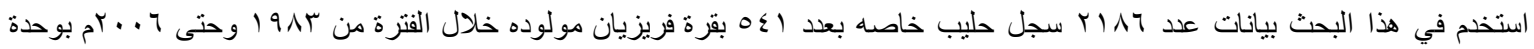

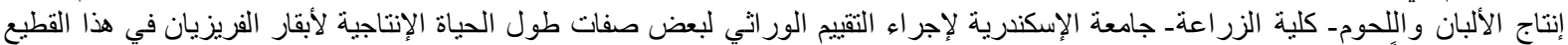

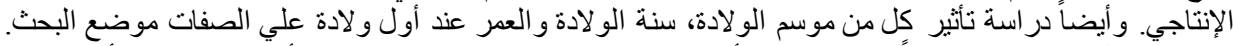

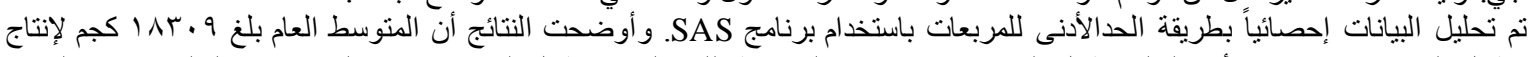

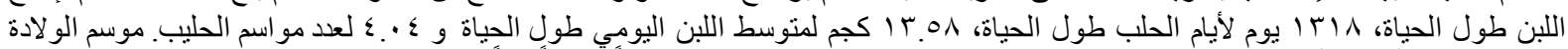

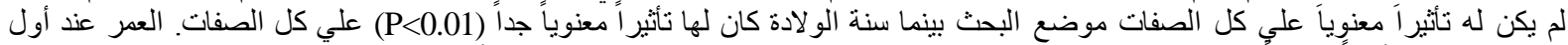

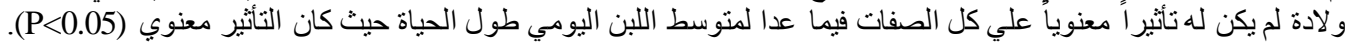

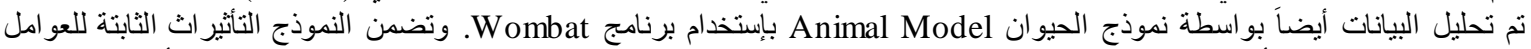

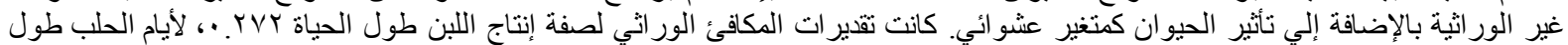

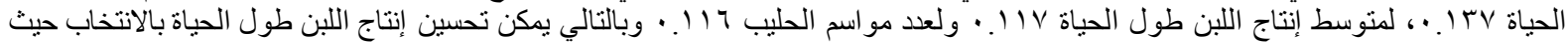

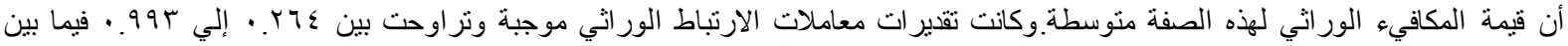

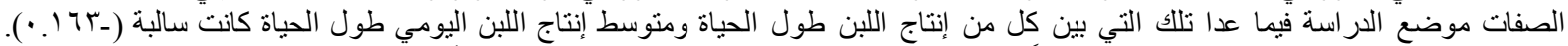

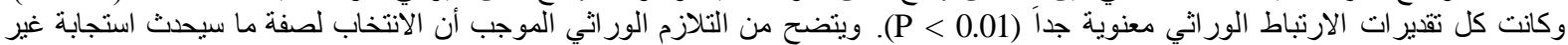

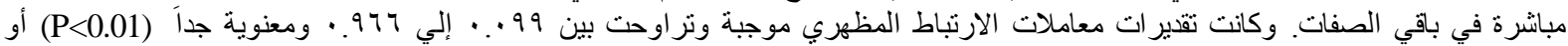
معنوية (P<0.05)

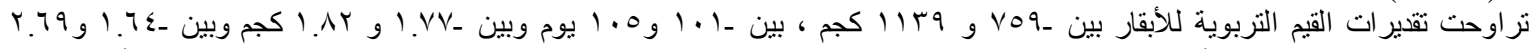

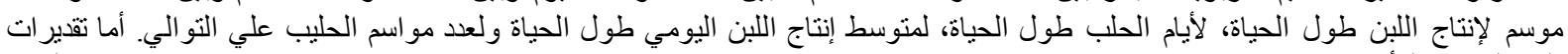

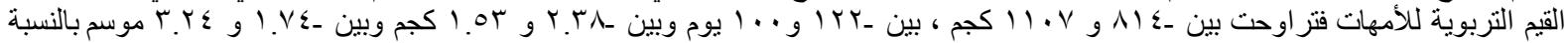

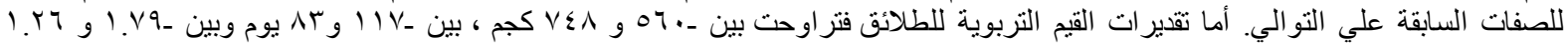

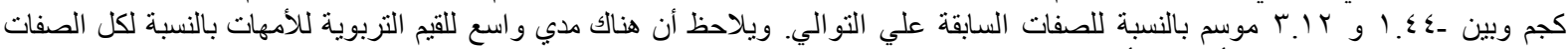
مقارنة بالقيم التربوية لكل من الأبقار و الأباء.

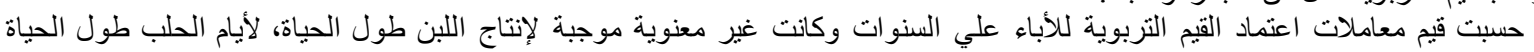

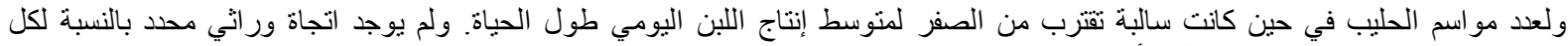
الصفات وذللك لغياب الانتخاب الفعال للأباء.

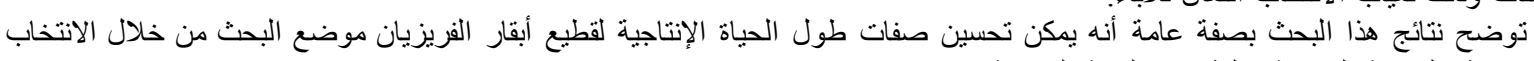

